\title{
A study to compare the clinical outcome of sublingual and vaginal misoprostol in the medical management of missed miscarriage in first trimester
}

\author{
Akanksha Lamba*, Ramanjeet Kaur, Priya Sardana
}

Department of Obstetrics \& Gynecology, Kasturba Hospital, New Delhi, India

Received: 12 January 2016

Accepted: 29 January 2016

\section{*Correspondence:}

Dr. Akanksha Lamba,

E-mail: dr.akanksha2709@gmail.com

Copyright: (C) the author(s), publisher and licensee Medip Academy. This is an open-access article distributed under the terms of the Creative Commons Attribution Non-Commercial License, which permits unrestricted non-commercial use, distribution, and reproduction in any medium, provided the original work is properly cited.

\begin{abstract}
Background: Objective of the study was to compare the efficacy, outcome and side effects of sublingual and vaginal misoprostol for the medical management of missed miscarriage.

Methods: Fifty women diagnosed as having missed miscarriage of gestational age less than 20 weeks were randomized to vaginal or sublingual route of drug administration by lottery method (random sampling) A total number of 25 cases in each of the two groups were considered. Women in Group A received 400 microgram of misoprostol sublingually every four hours for a maximum of 5 doses and those in Group B received 400 microgram of misoprostol vaginally every four hours for a maximum of 5 doses. The primary outcome measures were, complete evacuation of products of conception, mean induction to delivery time and the occurrence of side effects.

Results: In complete evacuation rates between the sublingual misoprostol and the vaginal misoprostol groups there was no statistically significant difference. Mean induction to delivery time was also similar for both groups as was the total number of doses required. As far as Side effects were concerned, Diarrhea was the major frequent side effect of sublingual misoprostol seen in $32 \%$ cases against only $12 \%$ cases with vaginal misoprostol.

Conclusions: The effectiveness of Sublingual misoprostol is comparable to that of vaginal misoprostol for medical management of missed miscarriage but is associated with an increased risk of side effects especially diarrhoea.
\end{abstract}

Keywords: Misoprostol, Sublingual, Vaginal, Missed miscarriage

\section{INTRODUCTION}

Miscarriage occurs in $10-20 \%$ of clinical pregnancies. ${ }^{1}$ Missed abortion is defined as a pregnancy in which there is no embryo (empty sac) or unrecognized foetal death. Women experiencing a missed abortion generally have little or no bleeding and no other overt signs or symptoms. ${ }^{2}$ It may also be referred to as blighted ovum, silent miscarriage, anembryonic or non-viable pregnancy, or foetal or embryonic demise. ${ }^{3}$ Causes of such miscarriages include anembryonic gestation, foetal chromosomal abnormalities, maternal diseases, placental abnormalities, and uterine anomalies. Treatment options of missed miscarriage include expectant management (waiting for spontaneous expulsion), medical management (administration of misoprostol), surgical management (evacuation of the uterus under anaesthesia). The increased concern in deciding the mode of treatment is due to closed cervical os and possibility of adherence of products of conception to the uterine wall. Expectant management has a high failure rate and is associated with the emotional distress of carrying a nonviable fetus. ${ }^{4}$ Missed miscarriages are commonly and successfully managed by surgical evacuation but it is associated with complications like uterine perforation, excessive bleeding, infection, cervical injury and asherman's syndrome as a late sequel. ${ }^{5}$ Medical management with the use of prostaglandin analogues like misoprostol with or without antiprogesterone priming is well established in clinical practice. ${ }^{6}$ In the management of missed 
miscarriages, use of misoprostol alone without antiprogesterone is valid as level of progesterone declines due to foetal demise. ${ }^{7}$ Medical management with misoprostol with its high expulsion rate has reduced the need of surgical evacuation. ${ }^{8}$ Misoprostol can be administered by various routes and in different doses. The objective of this study was to compare the efficacy, outcome and side effects of sublingual and vaginal misoprostol for the medical management of missed miscarriage.

\section{METHODS}

This prospective randomized study was carried out in the department of obstetrics and gynecology, Kasturba hospital, New Delhi over a period of four months (May 2015 to August 2015). A total of fifty women diagnosed as missed miscarriage on pelvic examination and ultrasound were admitted. Missed miscarriage is characterized by closed cervix and minimal or no bleeding per vaginum. On ultrasound it is defined as an intrauterine gestational sac with a mean sac diameter of $25 \mathrm{~mm}$ or more with no visible embryonic pole, an embryonic pole of more than $7 \mathrm{~mm}$ with no cardiac activity or persistent absence of cardiac activity on a second scan at least 7 to 10 days later ${ }^{9}$ Women with suspected ectopic pregnancy, excessive bleeding per vaginum, incomplete miscarriage, hemodynamically unstable, history of asthma, previous cesarean or allergy to prostaglandins were excluded from this study. We used and assigned blocks of four randomizations to two groups of participants. Gestational age was calculated from last menstrual period or ultrasonography. Complete history taking, physical examination, hemogram and coagulation profile were done. Women were explained about the medical and surgical management and written consent was taken. They were randomized to vaginal or sublingual route of drug administration by lottery method (random sampling). A total number of 25 cases in each of the two groups were considered. Women in group A received 400microg of misoprostol sublingually every four hours for a maximum of 5 doses and those in Group $B$ received 400 microgram of misoprostol vaginally every four hours for a maximum of 5 doses. After misoprostol administration, pulse, blood pressure, and temperature were recorded at an interval of four hours. Women were observed for uterine contractions, bleeding per vaginum, and expulsion of fetus. If the patient had strong uterine contractions, per vaginum examination was done and next dose was decided accordingly. Side effects like nausea, vomiting, diarrhea, fever, and significant vaginal bleeding were noted and patients were provided with symptomatic treatment. Fever was defined as temperature more than 100 degrees F. Diarrhea and vomiting were recorded if more than two episodes occurred. Excessive blood loss (more than $500 \mathrm{ml}$ ) and the need for blood transfusion were also noted. ${ }^{10}$ After expulsion, products of conception were examined. Structured proformas were filled with information regarding age, parity, gestational age, ultrasound findings, number of doses of misoprostol administered, induction to abortion interval, side effects, outcome of the treatment. Ultrasound was done to rule out retained products of conception in women who expelled. Incomplete miscarriage is when the intrauterine tissue diameter on ultrasound scan is $\geq 15 \mathrm{~mm}$. ${ }^{11}$ Primary outcome measure was complete expulsion of the products of conception without surgical intervention. Secondary outcome measures were failure of treatment, incomplete miscarriage, induction to abortion interval and side effects. Failure was defined as cases with incomplete or no dilatation within 12 hours of last dose of misoprostol. Induction abortion interval was defined as the time interval between administrations of first dose of misoprostol up to the time when the fetus was expelled. Surgical evacuation was considered for those who failed to abort after receiving 5 doses of misoprostol and those who had incomplete miscarriage. Cases were observed for 6 to 12 hours after surgical evacuation for bleeding per vaginum and vitals were monitored. Subjective assessment of the patients comfort was done during the time of discharge. Statistical analysis was performed by using software package Stata. Statistical analysis was done to assess the significance of variables and $p$-value less than 0.05 was considered as statistically significant.

\section{RESULTS}

Table 1 shows the demographic Profile of the women diagnosed with missed abortion. It clearly depicts that there was no significant difference with respect to age, parity and mean gestational age between the two groups.

Table 1: The demographic profile of the women.

\begin{tabular}{|lllll|}
\hline S. & $\begin{array}{l}\text { Demographic } \\
\text { Profile }\end{array}$ & $\begin{array}{l}\text { Sublingual } \\
\text { Misoprost } \\
\text { ol }(\mathbf{n = 2 5})\end{array}$ & $\begin{array}{l}\text { Vaginal } \\
\text { Misoprost } \\
\text { ol }(\mathbf{n = 2 5})\end{array}$ & $\begin{array}{l}\text { P- } \\
\text { valu } \\
\text { e }\end{array}$ \\
\hline $\mathbf{1}$ & $\begin{array}{l}\text { Mean age in } \\
\text { years }\end{array}$ & $24.92 \pm 3.17$ & $\begin{array}{l}24.48 \pm \\
3.41\end{array}$ & $\begin{array}{l}0.76 \\
0\end{array}$ \\
\hline $\mathbf{2}$ & $\begin{array}{l}\text { Parity- } \\
\text { Primigravida }\end{array}$ & 12 & 10 & 0.73 \\
\hline $\mathbf{3}$ & $\begin{array}{l}\text { Parity- } \\
\text { Multigravida }\end{array}$ & 13 & 15 & 4 \\
\hline $\mathbf{4}$ & $\begin{array}{l}\text { Mean } \\
\text { gestational } \\
\text { age in weeks }\end{array}$ & $9.42 \pm 2.05$ & $9.55 \pm 2.43$ & 0.84 \\
\hline
\end{tabular}

Table 2 depicts the clinical outcome of medical management of missed miscarriage. The key parameters it covered include complete miscarriage rate, failure, need of surgical Intervention, mean induction to abortion interval in hours, mean No. of doses required for complete miscarriage and excessive vaginal bleeding requiring blood transfusion. The mean induction to abortion interval was shorter in the sublingual group as compared to the vaginal group but this difference was statistically not significant. 
Table 2: Clinical outcome of medical management of missed miscarriage.

\begin{tabular}{|c|c|c|c|c|}
\hline $\begin{array}{l}\text { S. } \\
\text { No }\end{array}$ & $\begin{array}{l}\text { Clinical } \\
\text { outcome }\end{array}$ & $\begin{array}{l}\text { Sublingual } \\
\text { Misoprostol } \\
(\mathrm{n}=25)\end{array}$ & $\begin{array}{l}\text { Vaginal } \\
\text { Misopro } \\
\text { stol } \\
(\mathrm{n}=25)\end{array}$ & $\begin{array}{l}\text { P- } \\
\text { value }\end{array}$ \\
\hline 1 & $\begin{array}{l}\text { Complete } \\
\text { miscarriage } \\
\text { rate: } \mathrm{n}(\%)\end{array}$ & $17(68 \%)$ & $15(60 \%)$ & 0.571 \\
\hline 2 & Failure & $04(16 \%)$ & $05(20 \%)$ & 0.557 \\
\hline 3 & $\begin{array}{l}\text { Need of } \\
\text { surgical } \\
\text { intervention }\end{array}$ & $08(32 \%)$ & $10(40 \%)$ & 0.404 \\
\hline 4 & $\begin{array}{l}\text { Mean } \\
\text { induction to } \\
\text { abortion } \\
\text { interval in } \\
\text { hours }\end{array}$ & $11.67 \pm 6.90$ & $\begin{array}{l}18.33 \pm \\
5.60\end{array}$ & 0.931 \\
\hline 5 & $\begin{array}{l}\text { Mean No. of } \\
\text { doses } \\
\text { required for } \\
\text { complete } \\
\text { miscarriage }\end{array}$ & $3.29 \pm 1.02$ & $\begin{array}{l}4.2 \pm \\
0.85\end{array}$ & 0.754 \\
\hline 6 & $\begin{array}{l}\text { Excessive } \\
\text { vaginal } \\
\text { bleeding } \\
\text { requiring } \\
\text { blood } \\
\text { transfusion }\end{array}$ & $01(4 \%)$ & $01(4 \%)$ & 0.837 \\
\hline
\end{tabular}

Table 3 shows the side effects of misoprostol in both groups. Side effects were significantly more frequent in the sublingual group compared to the vaginal group.

Table 3: Side effects of misoprostol in both groups of medical management of missed miscarriage.

\begin{tabular}{|lllll|}
\hline $\begin{array}{l}\text { S. } \\
\mathbf{N}\end{array}$ & Side effects & $\begin{array}{l}\text { Sublingual } \\
\text { Misoprostol } \\
\text { 0. }\end{array}$ & $\begin{array}{l}\text { Vaginal } \\
\text { Misoprostol } \\
(\mathbf{n = 2 5})\end{array}$ & $\begin{array}{l}\text { P- } \\
\text { value }\end{array}$ \\
\hline $\mathbf{1}$ & $\begin{array}{l}\text { Unpleasant } \\
\text { taste }\end{array}$ & $\begin{array}{l}15(60 \%) \\
1(4 \%)\end{array}$ & 0.01 \\
\hline $\mathbf{2}$ & Vomiting & $10(40 \%)$ & $12(48 \%)$ & 0.876 \\
\hline $\mathbf{3}$ & Nausea & $18(72 \%)$ & $20(80 \%)$ & 0.98 \\
\hline $\mathbf{4}$ & Diarrhoea & $08(32 \%)$ & $03(12 \%)$ & 0.35 \\
\hline $\mathbf{5}$ & Shivering & $12(24 \%)$ & $5(4 \%)$ & 0.42 \\
\hline $\mathbf{6}$ & Fever & $10(40 \%)$ & $4(16 \%)$ & 0.78 \\
\hline
\end{tabular}

Diarrhoea was the major frequent side effect of sublingual misoprostol seen in $32 \%$ cases against only $12 \%$ cases with vaginal misoprostol.

Table 4 shows the level of comfort of the patient during administration of the drug. Sublingual route was better accepted by the cases.

\section{Table 4: Subjective assessment of comfort during administration of the drug.}

\begin{tabular}{|c|c|c|}
\hline $\begin{array}{l}\text { Level of comfort } \\
\text { during } \\
\text { administration of } \\
\text { the drug }\end{array}$ & $\begin{array}{l}\text { Sublingual } \\
\text { Misoprostol } \\
(\mathbf{n}=\mathbf{2 5})\end{array}$ & $\begin{array}{l}\text { Vaginal } \\
\text { Misoprost } \\
\text { ol } \\
(\mathbf{n}=\mathbf{2 5})\end{array}$ \\
\hline Comfortable & $22(88 \%)$ & $13(52 \%)$ \\
\hline Showed discomfort & 02 & 12 \\
\hline
\end{tabular}

\section{DISCUSSION}

Misoprostol is a synthetic prostaglandin $E_{1}$ analogue which is used for various indications like induction of abortions, medical management of miscarriage, cervical ripening before surgical procedures, induction of labour and management postpartum haemorrhage. ${ }^{12}$ When used for medical management of missed miscarriage it can be administered orally, vaginally or sublingually. A number of studies have demonstrated that it is safe and efficient for achieving fetal expulsion. In our study both the groups were comparable with regards to age, parity and gestational age. Complete abortion rates achieved in both the groups are comparable to those observed in a study done by Sonsanoh et al in Thailand. ${ }^{13}$ Tang Os et al ${ }^{14}$ and Zhang $\mathbf{J}$ et $\mathrm{al}^{15}$ observed a much higher complete abortion rate $(87.5 \%$ and $88 \%$ respectively) than our study which may be attributed to the higher dose of misoprostol used in their study. Also, we subjected our cases to surgical evacuation if expulsion was not achieved with five doses; further repeat doses were not given which may also be the cause of low success rate. The difference in the complete miscarriage rates of first trimester missed miscarriages between the two groups was found to be statistically insignificant which was similar to that observed in the other studies as well. ${ }^{14,16}$ The induction to abortion interval was shorter in the sublingual group than the vaginal group but the difference was statistically insignificant. This may be due to the shortest time to peak concentration, highest peak concentration and greatest bioavailability of the sublingual administration of the drug. ${ }^{17}$ Misoprostol is rapidly absorbed through the sublingual mucosa because of its rich blood supply and neutral $\mathrm{pH}$ of the buccal cavity. The induction to abortion interval is longer in the vaginal administration but has a similar successful abortion rate. This can be explained by the fact that although the peak concentration of misoprostol attained is lower by vaginal route but it is sustained at that level for a longer period of time. ${ }^{18}$ In our study the side effects were significantly more frequent in the sublingual group as compared to the vaginal group. Unpleasant taste was commonly $(60 \%)$ experienced by the women in sublingual group. Another study has reported a significantly increased frequency of unpleasant taste in women taking sublingual misoprostol. ${ }^{19}$ Other side effects like diarrhea, shivering and fever were also more common in the sublingual group has also seen by Tang OS et al. ${ }^{20}$ Increased incidence of fever with sublingual 
route may be due to the higher peak concentration of misoprostol which acts both on the uterine receptors and receptors involved in temperature regulation. Amongst the two routes, sublingual route was regarded as more convenient and was better accepted by the cases.

\section{CONCLUSIONS}

Sublingual and vaginal misoprostol are equally effective in the management of first trimester missed miscarriages. Sublingual route is better accepted by the patients but it is frequently associated with side effects.

Funding: No funding sources

Conflict of interest: None declared

Ethical approval: The study was approved by the Institutional Ethics Committee

\section{REFERENCES}

1. Alberman E. Spontaneous abortion: epidemiology. In:Stabile S, Grudzinkas G, Chard T, editors. Spontaneous abortion: diagnosis and treatment. London: Springer- Verlag; 1992:9-20.

2. Gemzell-Danielsson K, Ho PC, Gómez Ponce de León R, Weeks A, Winikoff B. Misoprostol to treat missed abortion in the first trimester. Intern $\mathbf{J}$ Gynecol Obstet. 2007;99(2):S182-5.

3. Cunningham FG, Leveno KJ, Gilstrap LC. III, Hauth JC, Wenstrom KD, Bloom SL. Williams Obstetrics. $22^{\text {nd }}$ Edition, McGraw-Hill; 2005.

4. Bagratee JS, Khullar V, Regan L, Moodley J, Kagoro H. A randomized controlled trial comparing medical and expectant management of first trimester miscarriage. Hum Reprod. 2004;19:266-71.

5. Robson SC, Kelly T, Howel D, Deverill M, Hewison J, Lie MLS. Randomized preference trial of medical versus surgical termination of pregnancy less than 14 weeks gestation (TOPS). Health Technol Assess. 2009;13:53.

6. Chung TKH, Cheung LP, Lau WC, Haines CJ, Chang AM. Spontaneous abortion: a medical approach to management. Aust N Z J Obstet Gynaecol. 1994;34:432-6.

7. Koopersmith TB, Mishell DR. The use of misoprostol for termination of early pregnancy. Contraception. 1996;57:237-42.

8. Zhang J, Giles JM, Barnhart K, Creinin MD, Westhoff C, Frederick MM. A comparison of medical management with misoprostol and surgical management for early pregnancy failure. N Engl J Med. 2005;353:761-9.

9. Bernard KG, Cooperburg PL. Sonographic differentiation between blighted ovum and early viable pregnancy. Am J Roentgenol. 1985;144:597602.
10. Management of post abortion hemorrhage, society of family planning, guidelines, 2013.

11. Management of early pregnancy miscarriage, Clinical practice guidelines, Institute of obstetricians and gynecologists. Royal college of physicians of Ireland and directorate of strategy and clinical programmes, Health Service Executive. Guideline no 10. April 2012.

12. Cunningham FG; Williams Obstetrics. $23^{\text {rd }}$ edition, McGraw Hill Company; 2010:215-234.

13. Sonsanoh A, Chullapram T. Comparison of sublingual and vaginal misoprostol for termination of early pregnancy failure. Thai J Obstet Gynaecol. 2014;22:128-36.

14. Tang OS, Lau WNT, Ng EHY, Lee SWH, Ho PC. A prospective randomized study to compare the use of repeated doses of vaginal with sublingual misoprostol in the management of first trimester silent miscarriages. Hum Reprod. 2003;18:176-81.

15. Zhang J, Gilles JM, Barnhart K, Creinin MD, Westhoff C, Frederick MM et al for the National Institute of Child Health Human Development (NICHD) management of early pregnancy failure trial. A comparison of medical management with misoprostol and surgical management for early pregnancy failure. New England $J$ Med. 2005;353(8):761-9.

16. Latif S, Usmani SY, Fatima N. Comparison of sublingual and vaginal routes of misoprostol in termination of first trimester missed abortion. Headache. 3:10.

17. Tang OS, Schweer H, Seyberth HW, Lee SW, Ho PC. Pharmacokinetics of different routes of administration of misoprostol. Hum Reproduct. 2002;17:332-6.

18. Tang OS, Gemzell-Danielsson K, Ho PC. Misoprostol: pharmacokinetic profiles, effects on the uterus and side effects. Int $\mathbf{J}$ gynecol Obstet. 2007;99(2):S160-7.

19. Hamoda H, Ashok PW, Pow J, Flett GM, Templeton A. A pilot study of mifepristone in combination with sublingual or vaginal misoprostol for medical termination of pregnancy up to 63 days gestation. Contraception. 2003;68:335-8.

20. Tang OS, Miao BY, Ho PG. Pilot study on the use of repeated doses of sublingual in termination of pregnancy: efficacy and acceptability. Hum Reprod. 2002; 17:654-8.

Cite this article as: Lamba A, Kaur R, Sardana P. A study to compare the clinical outcome of Sublingual and vaginal misoprostol in the medical management of missed miscarriage in first trimester. Int J Reprod Contracept Obstet Gynecol 2016;5:491-4. 